\title{
REFERENCES
}

Albury, K. (2015). Selfies, sexts, and sneaky hats: Young people's understandings of gendered practices of selfrepresentation. International Journal of Communication, 9, 1734-1745.

Albury, K. (2018). Sexual expression in social media. In J. Burgess, T. Poell, \& A. Marwick (Eds.), The SAGE handbook of social media (pp. 444-462). London: SAGE Publications.

Albury, K., Crawford, K., Byron, P., \& Matthews, B. (2013). Young people and sexting in Australia: Ethics, representation and the law. Sydney, NSW: ARC Centre for Creative Industries and Innovation/Journalism and Media Research Centre, UNSW. Retrieved from https://eprints.qut.edu.au/ 109550/1/Young_People_And_Sexting_Final.pdf

Alexander, J. (2019). Verizon is selling Tumblr to WordPress' owner. The Verge, August 12. Retrieved from https:// www.theverge.com/2019/8/12/20802639/tumblr-verizonsold-wordpress-blogging-yahoo-adult-content

Andalibi, N., Haimson, O. L., De Choudhury, M., \& Forte, A. (2018). Social support, reciprocity, and anonymity in responses to sexual abuse disclosures on social media. ACM Transactions on Computer-Human Interaction, 25(5), 1-35. doi:10.1145/ 3234942 
Ashley, V. (2018). Porn on Tumblr-A eulogy/love letter. Medium, December 7. Retrieved from https://medium.com/@ vexashley/porn-on-tumblr-a-eulogy-love-letter-6d45e70fefff

Bamman, D., O’Connor, B., \& Smith, N. (2012). Censorship and deletion practices in chinese social media. First Monday, 17(3). Retrieved from https://firstmonday.org/article/view/ 3943/3169

Baym, N. K. (2000). Tune in, log on: Soaps, fandom, and online community. Thousand Oaks, CA: SAGE Publications. Baym, N. K. (2015). Personal connections in the digital age (2nd ed.). Malden, MA: Polity Press.

Belam, M. (2017). Ted Cruz Twitter account 'likes' pornographic tweet. The Guardian, September 12. Retrieved from https://www.theguardian.com/us-news/2017/sep/12/tedcruz-twitter-account-likes-pornographic-tweet

Borges, A. (2019). 37 confessions about sex that will make you feel less alone. BuzzFeed, January 23. Retrieved from https://www.buzzfeed.com/annaborges/confessions-aboutsex-shame-and-insecurity

Bourdieu, P. (1977 [1972]). Outline of a theory of practice, trans. R. Nice. Cambridge: Cambridge University Press.

boyd, d., \& Jenkins, H. (2006). MySpace and Deleting Online Predators Act (DOPA). MIT Tech Talk, May 26. Retrieved from http://www.danah.org/papers/MySpaceDOPA.html

Breslow, J. (2018). Moderating the 'worst of humanity': Sexuality, witnessing, and the digital life of coloniality. Porn Studies, 5(3), 225-240.

Bucher, T., \& Helmond, A. (2017). Social media affordances and interfaces. In J. Burgess, T. Poell, \& A. Marwick (Eds.), SAGE handbook of social media. London: SAGE Publications. 
Captain, S. (2018). Tumblr's NSFW castaways are flocking to these lifeboats as a ban looms. Fast Company, December 14. Retrieved from https://www.fastcompany.com/90281686/ tumblr-alternatives-castaways-are-flocking-to-before-sundaysnsfw-ban

CNN. (1998). Clinton braces for historic testimony. CNN, August 16. Retrieved from https://edition.cnn.com/ ALLPOLITICS/1998/08/16/he.said.she.said.02/

Cohen, S. (1972). Folk devils and moral panics: The creation of the Mods and Rockers. London: MacGibbon \& Kee.

Colmenares-Guillén, L. E., \& Albores Velasco, F. J. (2016). Filter for web pornographic contents based on digital image processing. International Journal of Combinatorial Optimization Problems and Informatics, 7(2), 13-21.

Cooper, A., Delmonico, D. L., Griffin-Shelley, E., \& Mathy, R. M. (2004). Online sexual activity: An examination of potentially problematic behaviors. Sexual Addiction o Compulsivity, 11, 129-143.

Couldry, N. (2012). Media, society, world: Social theory and digital media practice. Cambridge: Polity Press.

Crofts, T., Lee, M., McGovern, A., \& Milivojevic, S. (2015). Sexting and young people. London: Palgrave Macmillan.

Donath, J. (1999). Identity and deception in the virtual community. In P. Kollock \& M. Smith (Eds.), Communities in cyberspace (pp. 27-57). London: Routledge.

D’Onofrio, J. (2018, December 3). A better, more positive Tumblr. Tumblr. Retrieved from https://staff.tumblr.com/ post/180758987165/a-better-more-positive-tumblr 
Döring, N. (2009). The internet's impact on sexuality: A critical review of 15 years of research. Computers in Human Behavior, 25(5), 1089-1101.

Ello. (2019a). Terms of service. Ello. Retrieved from https:// ello.co/wtf/policies/terms/

Ello. (2019b). Community guidelines. Ello. Retrieved from https:/ello.co/wtf/policies/community-guidelines/

Facebook. (2005). Terms of use. Wayback Machine. Retrieved from https://web.archive.org/web/20060203041141/http:// www.facebook.com/terms.php

Facebook. (2010). Statement of rights and responsibilities. Wayback Machine. Retrieved from https://web.archive.org/ web/20100430203955/http:/www.facebook.com/terms.php

Facebook. (2018). Community standards. Wayback Machine. Retrieved from https:/web.archive.org/web20180602024331/ http://www.facebook.com/communitystandards/ objectionable_content/

Facebook Community Standards. (2019). Adult nudity and sexual activity. Facebook Community Standards. Retrieved from https://www.facebook.com/communitystandards/ adult_nudity_sexual_activity

Farman, J. (2012). Mobile interface theory: Embodied space and locative media. New York, NY: Routledge.

FetLife. (2019). Content. FetLife. Retrieved from https:// fetlife.com/guidelines/content

Foucault, M. (1990). The history of sexuality. New York, NY: Vintage Books.

Fox46. (2019, July 12). Investigators say sex trafficker found victims through social media. Fox46 Charlotte. Retrieved 
from https://www.fox 46 charlotte.com/news/investigators-saysex-trafficker-found-victims-through-social-media

Frishberg, H. (2019). 'Sexual' use of eggplant and peach emojis banned on Facebook, Instagram. New York Post, October 29. Retrieved from https://nypost.com/2019/10/29/sexual-use-ofeggplant-and-peach-emojis-banned-on-facebook-instagram/

Gallagher, B. (2018). How to turn down a billion dollars: The Snapchat story. New York, NY: St. Martin's Press.

Gallagher, S. (2019). Cyber flashing: Why are men still sending women unsolicited dick pics? Huffpost, July 12. Retrieved from https://www.huffingtonpost.co.uk/entry/cyberflashing-why-aremen-still-sending-women-unsolicited-dick-pics_uk_5bdc278fe4 b04367a87b755e

Gan, E. (2019). Syphilis is not dead: Dating apps, HIV pill, risky sex help push disease to forefront again. Today, July 13. Retrieved from https://www.todayonline.com/singapore/syphilis-not-deaddating-apps-hiv-pill-risky-sex-help-push-disease-forefront-again

Ganguly, D., Mofrad, M. H., \& Kovashka, A. (2017). Detecting sexually provocative images. In IEEE Winter conference on applications of computer vision (pp. 660-668). Retrieved from https://people.cs.pitt.edu/ kovashka/ganguly_mofrad_kovash ka_wacv2017.pdf

Gehl, R. (2015). The case for alternative social media. Social Media + Society, 1(2), 1-12.

Giddens, A. (1992). The transformation of intimacy: Sexuality, love, and eroticism in modern societies. Cambridge: Polity Press.

Gill, E., \& Yedroudj, L. (2019). Woman poses as 14-year-old on social media apps and is bombarded with sex texts. Mirror, July 11. Retrieved from https://www.mirror.co.uk/news/uknews/woman-poses-14-year-old-17959300 
Gillespie, T. (2017). Governance of and by platforms. In J. Burgess, A. Marwick, \& T. Poell (Eds.), The SAGE handbook of social media (pp. 254-278). London: SAGE Publications.

Goffman, E. (1959). The presentation of self in everyday life. Garden City, NY: Doubleday.

Goffman, E. (1963). Behavior in public places: Notes on the social organization of gatherings. New York, NY: Free Press of Glencoe.

Granovetter, M. (1974). Getting a job: A study of contacts and careers. Cambridge: Harvard University Press.

Gynodiversity. (2018). Tumblr. Retrieved from https:// gynodiversity.tumblr.com/

Habib, C. (2015). The name of your first pet and the street you grew up on. In: J. Lee (Ed.), Coming out like a porn star: Essays on pornography, protection, and privacy. Berkeley, CA: Stone Bridge Press.

Habermas, J. (1989 [1962]). The structural transformation of the public sphere. Cambridge, MA: MIT Press.

Helmond, A. (2015). The platformization of the web: Making web data platform ready. Social Media + Society, July-December, 1-11.

Instagram. (2019). Why are certain posts not appearing in explore and hashtag pages? Instagram Help. Retrieved from https:/help.instagram.com/613868662393739

James, A., \& Webster, A. (2018). "I never realised they were so different": Understanding the impact of the Labia Library (pp. 1-19). Melbourne, VIC: Women's Health Victoria. Retrieved from https://whv.org.au/resources/whv-publications/i-neverrealised-they-were-so-different-understanding-impact-labia 
Koskela, H. (2004). Webcams, TV shows and mobile phones: Empowering exhibitionism. Surveillance and Society, 2(2/3), 199-215.

Krinsky, C. (2013). Introduction: The moral panic concept. In C. Krinsky (Ed.), The Ashgate research companion to moral panics (pp. 1-15). London: Routledge.

Liao, S. (2019). After the porn ban, Tumblr users have ditched the platform as promised. The Verge, March 14. Retrieved from https://www.theverge.com/2019/3/14/18266013/tumblrporn-ban-lost-users-down-traffic

Light, B. (2014). Disconnecting with social networking sites. Basingstoke: Palgrave Macmillan.

Maia, D. (2015). Meet the Danish revenge porn victim who's fighting back with nude photos. Vice, February 27. Retrieved from https://www.vice.com/sv/article/qb5 pjm/meet-therevenge-porn-victim-that-fought-back-with-nude-photos-202

Markham, A. N. (1998). Life online: Researching real experience in virtual space. Walnut Creek, CA: Altamira Press. Marx, G. T. (1999). What's in a name? Some reflections on the sociology of anonymity. The Information Society, 15(2), 99-112.

McGlynn, C., \& Rackley, E. (2017). Image-based sexual abuse. Oxford Journal of Legal Studies, 37(3), 534-561.

McKee, A., McNair, B., \& Watson, A.-F. (2015). Sex and the virtual suburbs: The pornosphere and community standards. In P. J. Maginn \& C. Steinmetz (Eds.), (Sub)urban sexscapes: Geographies and regulation of the sex industry (pp. 159-174). London: Routledge.

McMillan, D. W., \& Chavis, D. M. (1986). Sense of community: A definition and theory. Journal of Community Psychology, 14(1), 6-23. 
Molldrem, S. (2018). Tumblr's decision to deplatform sex will harm sexually marginalized people. Wussy Magazine, December 6. Retrieved from wussymag.com/all/2018/12/6/tumblrs-decisionto-deplatform-sex-will-harm-sexually-marginalized-people

Nagoski, E. (2015). Come as you are: The surprising new science that will transform your sex life. New York, NY: Simon and Schuster.

National Campaign to Prevent Teen and Unplanned Pregnancy. (2008). Sex and tech: Results from a survey of teens and young adults. Washington, DC: National Campaign to Prevent Teen and Unplanned Pregnancy. Retrieved from https://apo.org.au/ node/17127

News18.com. (2019, June 26). New age social media apps, and a shocking problem of borderline sexual content, News18.com. Retrieved from https://www.news18.com/news/tech/new-agesocial-media-apps-and-a-shocking-problem-of-borderlinesexual-content-2203779.html

Nikunen, K., \& Paasonen, S. (2007). Porn star as brand: Pornification and the intermedia career of Rakel Liekki. The Velvet Light Trap, 59, 30-41.

Nissenbaum, H. (2010). Privacy in context: Technology, policy, and the integrity of social life. Palo Alto, CA: Stanford University Press.

Paasonen, S. (2018). Online porn. In N. Brügger, I. Milligan, \& M. Ankerson (Eds.), The SAGE handbook of web history (pp. 551-563). London: SAGE Publications.

Paasonen, S., Jarrett, K., \& Light, B. (2019). NSFW: Sex, humor, and risk in social media. Cambridge, MA: MIT Press.

Pilkington, E. (2009). Sexting craze leads to child pornography charges. The Guardian, January 15. Retrieved 
from https:/www.theguardian.com/world/2009/jan/14/childpornography-sexting

Peterson, Z. D., \& Muehlenhard, C. L. (2007). What is sex and why does it matter? A motivational approach to exploring individuals' definitions of sex. The Journal of Sex Research, 44(3), 256-268.

Probyn, E. (2005). Blush, faces of shame. Minneapolis, MN: University of Minnesota Press.

Reddit. (2019). Content policy. Reddit. Retrieved from https:// www.redditinc.com/policies/content-policy

Rheingold, H. (1993). The virtual community: Homesteading on the electronic frontier. Cambridge, MA: MIT Press.

Ringrose, J., Harvey, L., Gill, R., \& Livingstone, S. (2013). Teen girls, sexual double standards and "sexting": Gendered value in digital image exchange. Feminist Theory, 14(3), 305-323.

Roberts, S. T. (2019). Behind the screen: Content moderation in the shadows of social media. New Haven, CT: Yale University Press.

Rubin, G. (1984). Thinking sex: Notes for a radical theory of the politics of sexuality. In P. Nardi \& B. Schneider (Eds.), Social perspectives in lesbian and gay studies (pp. 100-133). London: Routledge.

Salter, M. (2015). Privates in the online public: Sex(ting) and reputation on social media. New Media \& Society, 18(11), 2723-2739.

Sanders, S. A., \& Reinisch, J. M. (1999). Would you say you "had sex" if...? Journal of the American Medical Association, 281, 115-211. 
Smith, A., \& Anderson, M. (2018, March 1). Social media use 2018: Demographics and statistics. Pew Research Center. Retrieved from https://www.pewinternet.org/2018/03/01/ social-media-use-in-2018/

Smith, S. A., \& Cole, S. A. (2013). MyMoralPanic: Adolescents, social networking, and child sex crime panic. In C. Krinsky (Ed.), The Ashgate research companion to moral panics (pp. 207-223). London: Routledge.

Stasko, E. C., \& Geller, P. A. (2015). Reframing sexting as a positive relationship behavior (pp. 6-9). Washington, DC: American Psychological Association. Retrieved from https:// www.apa.org/news/press/releases/2015/08/reframingsexting.pdf

Stone, A. R. (1994). Split subjects, not atoms; or, how I fell in love with my prosthesis. Configurations, 2(1), 173-190.

Suler, J. (2004). The online disinhibition effect. CyberPsychology and Behavior, 7(3), 321-326.

Svedmark, E., \& Nyberg, A. (2009). Om det privata i publika och digitala rum. [About privacy in public and digital spaces.] In M. Nyman (Ed.), Semig: unga om sex och internet (pp. 354-383). [See me: Youth about sex and the internet.] Stockholm: Davidsons Tryckeri AB.

Taigman, Y., Yang, M., Ranzato, M., \& Wolf, L. (2014, June 24). DeepFace: Closing the gap to human-level performance in face verification. Facebook Research. Retrieved from https://research.fb.com/publications/deepfaceclosing-the-gap-to-human-level-performance-in-faceverification/

The Casual Sex Project. (2019). The Casual Sex Project. Retrieved from https:/casualsexproject.com/ 
Thompson, R. (2017, February 8). For better or worse, Snapchat changed sexting forever. Mashable. Retrieved from https://mashable.com/2017/02/07/snapchat-sextingrevolution/

Time Magazine. (1995). Cyberporn. Time Magazine, July 3. Retrieved from http://content.time.com/time/covers/ 0,16641,19950703,00.html

Tönnies, F. (2017 [1887]). In C. P. Loomis (Trans.), Community \& society. Eastford, CT: Martinon Fine Books. Tumblr staff. (2018, December 17). Hey Tumblr - A couple of weeks ago we announced an update to our community guidelines. Tumblr. Retrieved from https://staff.tumblr.com/ post/181199101690/hey-tumblr-a-couple-of-weeks-ago-weannounced-an

Twitter. (2019a). Terms of service. Twitter. Retrieved from https://twitter.com/en/tos

Twitter. (2019b). Settings. Twitter. Retrieved from http:// twitter.com/settings/safety

Ursal, C. (2019). Social media lures young people to engage in sex for money. Inquirer, June 22. Retrieved from https:// newsinfo.inquirer.net/1132932/social-media-lures-youngpeople-to-engage-in-sex-for-money

Vitis, L., \& Gilmour, F. (2016). Dick pics on blast: A woman's resistance to online sexual harassment using humour, art and Instagram. Crime, Media, Culture, 13(3), 335-355.

Waskul, D. D. (2007). Internet sex: The seductive "freedom to". In S. Seidman, N. L. Fischer, \& C. Meeks (Eds.), Introducing the new sexuality studies. Abingdon: Routledge.

Weeks, J. (1996). The idea of a sexual community. Soundings, 2, 71-84. 
West, S. M. (2018). Censored, suspended, shadow banned: User interpretations of content moderation on social media platforms. New Media \& Society, 20(11), 4366-4383.

Wilson, J. Q., \& Kelling, G. L. (1982, March 1). Broken windows: The police and neigborhood safety. The Atlantic, 249(3), 29-38.

xs51. (2014). The Gonewild FAQ. Reddit. Retrieved from https://www.reddit.com/r/gonewild/wiki/faq

YouTube. (2019). Community guidelines. YouTube. Retrieved from https://www.youtube.com/yt/about/policies/\#communityguidelines

Zhou, R., Hentschel, J., \& Kumar, N. (2017, May 2). Goodbye text, hello emoji: Mobile communication on WeChat in China. In Proceedings of the $2017 \mathrm{CHI}$ conference on human factors in computing systems (pp. 748-759).

\section{RECOMMENDED READINGS}

The journals Porn Studies, Sexualities, Social Media + Society, New Media \& Society, and Feminist Media Studies are all key within this field.

These books have more to say about sex and the internet generally:

Attwood, F. (2017). Sex media. Cambridge: Polity Press.

Nixon, P., \& Düsterhöft, I. K. (Eds.). (2018). Sex in the digital age. London: Routledge.

Paasonen, S., Jarrett, K., \& Light, B. (2019). NSFW:

Sex, humor, and risk in social media. Cambridge, MA:

MIT Press. 


\section{ADDITIONAL READING SUGGESTIONS BY TOPIC}

\section{Sexting \& Dick Pics}

Albury, K. (2015). Selfies, sexts, and sneaky hats: Young people's understandings of gendered practices of self-representation. International Journal of Communication, 9, 1734-1745.

Hasinoff, A. A. (2012). Sexting as media production: Rethinking social media and sexuality. New Media \& Society, 15(4), 449-465.

Hasinoff, A. A.(2015).Sexting panic:Rethinking criminalization, privacy, and consent. Urbana, IL: University of Illinois Press.

Hayes, R. M., \& Dragiewicz, M. (2018). Unsolicited dick pics: Erotica, exhibitionism or entitlement? Women's Studies International Forum, 71, 114-120.

Paasonen, S., Light, B., \& Jarrett, K. (2019, April-June). The dick pic: Harassment, curation, and desire. Social Media + Society, 5(2), 1-10.

Ringrose, J., \& Harvey, L. (2015). Boobs, back-off, six packs and bits: Mediated body parts, gendered reward, and sexual shame in teens' sexting images. Continuum, 29, 205-217.

Shields Dobson, A. (2018). Sexting, intimate and sexual media practices, and social justice. In A. Shields Dobson, B. Robards, \& N. Carah (Eds.), Digital intimate publics and social media (pp. 93-110). Cham: Palgrave Macmillan.

Waling, A., \& Pym, T. (2017). 'C'mon, no one wants a dick pic': Exploring the cultural framings of the 'dick pic' in contemporary online publics. Journal of Gender Studies, 28(1), 70-85. 
Walrave, M., Van Ouytsel, J., Ponnet, K., \& Temple, J. R. (Eds.). (2018). Sexting: Motives and risk in online sexual selfpresentation. Cham: Palgrave Macmillan.

\section{HOOK-UP APPS}

Albury, K., Burgess, J., Light, B., Race, K., \& Wilken, R. (2017). Data cultures of mobile dating and hook-up apps: Emerging issues for critical social science research. Big Data \& Society, $4(2), 1-11$.

Albury, K., \& Byron, P. (2016, October-December). Safe on my phone? Same-sex attracted young people's negotiations of intimacy, visibility, and risk on digital hook-up apps. Social Media + Society, 2(4), 1-10.

Duguay, S. (2017). Dressing up Tinderella: Interrogating authenticity claims on the mobile dating app Tinder. Information, Communication \& Society, 20(3), 351-367.

Hess, A., \& Flores, C. (2018). Simply more than swiping left: A critical analysis of toxic masculine performances on Tinder Nightmares. New Media \& Society, 20(3), 1085-1102.

Light, B. (2014). Producing sexual cultures and pseudonymous publics with digital networks. In R. A. Lind (Ed.), Race and gender in electronic media: Content, context, culture (pp. 231-246). London: Routledge.

\section{Social Media Affordances}

Bucher, T., \& Helmond, A. (2017). Social media affordances and interfaces. In J. Burgess, T. Poell, \& A. Marwick (Eds.), SAGE handbook of social media. London: SAGE Publications. 
Davis, J. L., \& Chouinard, J. B. (2017). Theorizing affordances: From request to refuse. Bulletin of Science, Technology \& Society, 36(4), 1-8.

Evans, S. K., Pearce, K. E., Vitak, J., \& Treem, J. W. (2017). Explicating affordances: A conceptual framework for understanding affordances in communication research. Journal of Computer-Mediated Communication, 22(1), 35-52.

Nagy, P., \& Neff, G. (2015, July-December). Imagined affordance: Reconstructing a keyword for communication theory. Social Media + Society, 1(2), 1-9.

\section{Social Media Audiences, Identities and Collapsing Contexts}

boyd, d. (2011). Social network sites as networked publics: Affordances, dynamics, and implications. In Z. Papacharissi (Ed.), A networked self: Identity, community, and culture on social network sites (pp. 39-58). New York, NY:

Routledge.

Light, B. (2014). Producing sexual cultures and pseudonymous publics with digital networks. In R. A. Lind (Ed.), Race and gender in electronic media: Content, context, culture (pp. 231-246). London: Routledge.

Litt, E. (2012). Knock, knock. who's there? The imagined audience. Journal of Broadcasting \& Electronic Media, 56(3), 330-345.

Litt, E., \& Hargittai, E. (2016). The imagined audience on social network sites. Social Media + Society, 2(1), 1-12.

Marwick, A. E., \& boyd, d. (2010). I tweet honestly, I tweet passionately: Twitter users, context collapse, and the imagined audience. New Media \& Society, 13(1), 114-133. 
Oolo, E., \& Siibak, A. (2013). Performing for one's imagined audience: Main online privacy strategies of Estonian teens. Cyberpsychology: Journal of Psychosocial Research on Cybe rspace, 7(1). Retrieved from https://cyberpsychology.eu/arti cle/view/4276/3319

\section{Porn}

Attwood, F. (2010). Porn.com: Making sense of online pornography. New York, NY: Peter Lang.

Jacobs, K., Janssen, M., \& Pasquinelli, M. (Eds.). (2007). C'lickme: A netporn studies reader. Amsterdam: Institute of Network Cultures.

McKee, A. (2012). Pornography as entertainment. Continuum: Journal of Media \& Cultural Studies, 26(4), 541-552.

Paasonen, S. (2010). Labors of love: Netporn, Web 2.0, and the meanings of amateurism. New Media \& Society, 12(8), 1297-1312.

Paasonen, S. (2011). Carnal resonance: Affect and online pornography. Cambridge, MA: MIT Press.

\section{Shame and Shaming}

Dobson, A. S. (2013). Performative shamelessness on young women's social network sites: Shielding the self and resisting gender melancholia. Feminism \& Psychology, 24(1), 97-114.

Levey, T. G. (2018). Sexual harassment online: Shaming and silencing women in the digital age. Boulder, CO: Lynne Rienner. Mercer, J. (2018). Sex positivity and the persistence of shame. Sexualities, 21(8), 1304-1307. 
Probyn, E. (2005). Blush, faces of shame. Minneapolis, MN: University of Minnesota Press.

Scheff, T. J. (2000). Shame and the social bond: A sociological theory. Sociological Theory, 18(1), 84-99.

Scheff, T. J. (2001). Shame and community: Social components in depression. Psychiatry, 64(3), 212-224.

Shah, N. (2015). The selfie and the slut: Bodies, technology and public shame. Economic and Political Weekly, 17, 86-93.

\section{LGBT Cultures and Communities Online}

Byron, P. (2019). 'How could you write your name below that?' The queer life and death of Tumblr. Porn Studies, 6(3), 336-349.

Cho, A. (2018). Default publicness: Queer youth of color, social media, and being outed by the machine. New Media o Society, 20(9), 3183-3200.

Dhoest, A., \& Szulc, L. (2016). Navigating online selves: Social, cultural, and material contexts of social media use by diasporic gay men. Social Media + Society, 2(4), 1-10.

Duguay, S. (2016, April-June). Lesbian, gay, bisexual, trans, and queer visibility through selfies: Comparing platform mediators across Ruby Rose's Instagram and vine presence. Social Media + Society, 2(2), 1-12.

Duguay, S., Burgess, J., \& Suzor, N. (2018). Queer women's experiences of patchwork platform governance on Tinder, Instagram, and Vine. Convergence, 1-16.

Hanckel, B., Vivienne, S., Byron, P., Robards, B., \& Churchill, B. (2019). 'That's not necessarily for them': LGBTIQ+ young people, social media platform affordances and identity curation. Media, Culture \& Society, 41(8), 1261-1278. 


\section{Embodiment Online}

Slater, D. (2002). Making things real: Ethics and order on the internet. Theory, Culture \& Society, 19(5/6), 227-245.

Sundén, J. (2003). Material virtualities: Approaching online textual embodiment. New York, NY: Peter Lang.

\section{Kat's and Emily's Relevant Scholarly Publications}

Allaste, A.-A., \& Tiidenberg, K. (2015). Sexy selfies of the transitioning self. In D. Woodman \& A. Bennett (Eds.), Youth cultures, belonging and transitions. London: Palgrave Macmillan. van der Nagel, E. (2013). Faceless bodies: Negotiating technological and cultural codes on Reddit Gonewild. Scan: Journal of Media Arts Culture, 10(2). Retrieved from http://scan.net.au/scn/journal/ vol10number2/Emily-van-der-Nagel.html

van der Nagel, E. (2017). From usernames to profiles: The development of pseudonymity in internet communication. Internet Histories: Digital Technology, Culture and Society, 1(4), 312-331. van der Nagel, E. (2018). Alts and automediality: Compartmentalising the self through multiple social media profiles. M/C Journal: A Journal of Media and Culture, 21(2). Retrieved from http://journal.media-culture.org.au/index.php/ mcjournal/article/view/1379

van der Nagel, E. (2020). Embodied verification: Linking identities and bodies on NSFW Reddit. In C. Cambre, C. Abidin, \& K. Warfield (Eds.), Mediated interfaces: The body on social media. New York, NY: Bloomsbury.

van der Nagel, E. (2020). Fluids on pictures on screens: Pseudonymous affect on Reddit's TributeMe. Social Media + Society, January-March, 1-9. 
van der Nagel, E., \& Frith, J. (2015). Anonymity, pseudonymity, and the agency of online identity: Examining the social practices of r/Gonewild. First Monday, 20(3). Retrieved from https:// firstmonday.org/ojs/index.php/fm/article/view/5615

Tiidenberg, K. (2013). How does online experience inform our sense of self? NSFW bloggers' identity narratives. In A.-A. Allaste (Ed.), Changes and continuities of lifestyles in transforming societies (pp. 177-203). New York, NY: Peter Lang.

Tiidenberg, K. (2014). Bringing sexy back: Reclaiming the body aesthetic via self shooting. Cyberpsychology: Journal of Psychosocial Research on Cyberspace, 8(1). Retrieved from https://cyberpsychology.eu/article/view/4295/3342.

Tiidenberg, K. (2016). Boundaries and conflict in a NSFW community on tumblr: The meanings and uses of selfies. New Media \& Society, 18(8), 1563-1578.

Tiidenberg, K. (2017). "Nude selfies til I die" - Making of sexy in selfies. In P. G. Nixon \& I. Düsterhöft (Eds.), Sex in the digital age. London: Routledge.

Tiidenberg, K. (2018). Selfies: Why we love (and hate) them. Bingley: Emerald Publishing.

Tiidenberg, K. (2019). Playground in memoriam: Missing the pleasures of NSFW tumblr. Porn Studies, 6(3), 363-371.

Tiidenberg, K., \& Gómez Cruz, E. (2015). Selfies, image and the re-making of the body. Body \& Society, 21, 77-102.

Tiidenberg, K., \& Paasonen, S. (2019, online first 2018). Littles: Affects and aesthetics in sexual age-play. Sexuality \& Culture, 23, 375-393.

Tiidenberg, K., \& Whelan, A. (2019). “Not like that, not for that, not by them": Social media affordances of critique.

Communication and Critical/Cultural Studies, 16(2), 83-102. 